\title{
Two types of nanoparticle-based bio-barcode amplification assays to detect HIV-1 p24 antigen
}

\author{
Huahuang Dong ${ }^{1}$, Jianli Liu², Hong Zhu², Chin-Yih Ou ${ }^{3}$ Wenge Xing ${ }^{1}$, Maofeng Qiu', Guiyun Zhang ${ }^{1}$, Yao Xiao',
} Jun Yao ${ }^{1}$, Pinliang Pan ${ }^{1}$ and Yan Jiang ${ }^{1 *}$

\begin{abstract}
Background: HIV-1 p24 antigen is a major viral component of human immunodeficiency virus type 1 (HIV-1) which can be used to identify persons in the early stage of infection and transmission of HIV-1 from infected mothers to infants. The detection of p24 is usually accomplished by using an enzyme-linked immunosorbent assay (ELISA) with low detection sensitivity. Here we report the use of two bio-barcode amplification (BCA) assays combined with polymerase chain reaction (PCR) and gel electrophoresis to quantify HIV-1 p24 antigen.
\end{abstract}

Method: A pair of anti-p24 monoclonal antibodies (mAbs) were used in BCA assays to capture HIV-1 p24 antigen in a sandwich format and allowed for the quantitative measurement of captured p24 using PCR and gel electrophoresis. The first $1 \mathrm{G} 12$ mAb was coated on microplate wells or magnetic microparticles (MMPs) to capture free p24 antigens. Captured p24 in turn captured 1D4 mAb coated gold nanoparticle probes (GNPs) containing double-stranded DNA oligonucleotides. One strand of the oligonucleotides was covalently immobilized whereas the unbound complimentary bio-barcode DNA strand could be released upon heating. The released bio-barcode DNA was amplified by PCR, electrophoresed in agarose gel and quantified.

Results: The in-house ELISA assay was found to quantify p24 antigen with a limit of detection (LOD) of 1,000 pg/ml and a linear range between 3,000 and 100,000 pg/ml. In contrast, the BCA-based microplate method yielded an LOD of $1 \mathrm{pg} / \mathrm{ml}$ and a linear detection range from 1 to $10,000 \mathrm{pg} / \mathrm{ml}$. The BCA-based MMP method yielded an LOD of $0.1 \mathrm{pg} / \mathrm{ml}$ and a linear detection range from 0.1 to $1,000 \mathrm{pg} / \mathrm{ml}$.

Conclusions: When combined with PCR and simple gel electrophoresis, BCA-based microplate and MMPs assays can be used to quantify HIV-1 p24 antigen. These methods are 3-4 orders of magnitude more sensitive than our in-house ELISA-based assay and may provide a useful approach to detect p24 in patients newly infected with HIV.

Keywords: Human immunodeficiency viruses, Bio-barcode amplification, p24 detection

\section{Introduction}

The early stage of HIV infection is characterized by the absence of detectable antibodies and transient high viral load. Patients in this window period have a high probability of HIV transmission [1,2]. Virologic markers such as HIV-1 RNA, DNA and p24 antigen can be used to determine infection status. The direct detection of viral nucleic acids using PCR-based approaches is of high technical complexity and requires skilled personnel, equipment and laboratory infrastructure. It is also complicated

\footnotetext{
*Correspondence: jiangyan03@263.net

'National HIV/HCV Reference Laboratory, National Center for AIDS/STD Control and Prevention, Chinese Center for Disease Control and Prevention, Beijing, The People's Republic of China

Full list of author information is available at the end of the article
}

by the high variation and continuing diversification of HIV viral genome and subtypes [3-5]. Detection of p24 antigen could serve as a viable alternative for the detection of infection during the window period [6-8] and in HIV-1 exposed infants $[9,10]$.

ELISA has been previously used for HIV-1 p24 antigen detection. Due to the interference of antibodies in infected persons, conventional ELISA assays can detect p24 in approximately 10\% asymptomatic infected persons and 30 to $40 \%$ patients with late stage AIDS-related syndrome [11]. Several modifications have been introduced to improve detection sensitivity by heat or acid disruption of antigen-antibody complexes [12], signal amplification based on tyramide [13] and immuno-PCR 
[14]. An ultra-sensitive BCA assay with GNPs was recently developed to detect proteins with special clinical significance [15]. To capture the antigen of interest, MMPs of $1 \mu \mathrm{m}$ in diameter are coated with a mAb to the antigen. Addition of GNPs dually labeled with a second $\mathrm{mAb}$ and bio-barcode DNA oligomers results in the formation of an antigen, antibody, DNA oligomer complex. The amount of the DNA oligomers co-captured is directly proportional to the amount of the antigen and can be quantitatively measured by chip-based scanometric method [15-20] and PCR [21,22]. Here we describe the use of two types of BCA assay with simple PCR and gel analysis to achieve HIV-1 p24 quantification.

\section{Results}

\section{Detection of HIV-1 p24 antigen by ELISA}

First, we examined the quantification of p24 antigen using an in-house ELISA assay with $1 \mathrm{G} 12$ and 1D4 $\mathrm{mAb}$ pair (Figure 1A). Serial dilutions of p24 antigens from 100,000 to $100 \mathrm{pg} / \mathrm{ml}$ were added to the microplate wells precoated with $1 \mathrm{G} 12 \mathrm{mAb}$ and then incubated with horseradish peroxidase labeled 1D4 mAb for colorimetric reaction. The average of 3 independent $\mathrm{OD}_{450}$ measurements of negative controls was 0.249 (standard deviation $\mathrm{SD}=0.014)$ and the cutoff $(\mathrm{CO})$ was 0.291 (= mean plus 3SD). The SD (Figure 2) and coefficient of variations (1.6-22.2\%) of the data point range were small. The LOD was $1,000 \mathrm{pg} / \mathrm{ml}$ (Figure 2). The signal and antigen response curve increased slowly and was linear in the range between 3,000 and $100,000 \mathrm{pg} / \mathrm{ml}$ (Figure 3A).

\section{PCR and gel detection of signal strand of bio-barcode DNA}

To improve the p24 detection sensitivity, we employed two types of BCA methods to capture p24 and then used PCR and gel electrophoresis to measure the amount of amplified bio-barcode DNA (Figure $1 \mathrm{~B}$ and C). To demonstrate the utility of PCR and gel electrophoresis to measure the bio-barcode DNA oligomer, we used unbound free single-stranded bio-barcode DNA oligomer $\left(3 \times 10^{9}\right.$ to 30 copies), amplified with a bio-barcode DNA specific primer pair for 25 cycles and examined the amplified product in a $4 \%$ agarose gel. As shown in Figure 4, clear DNA bands with anticipated 47 bp in length were detected in samples with input DNA of $3 \times 10^{9}$ to 3,000 copies (lanes $1 \sim 7$ ) but not in samples with input DNA of 300 copies and 30 copies (lanes 8 and 9, respectively). No bands or primer dimers were found after 25 cycles of PCR for the negative control (lane 10).

\section{Detection of HIV-1 p24 antigen by BCA using microplate}

With the establishment of the method to measure biobarcode oligomer using PCR and gel electrophoresis, we proceeded with the BCA-based microplate assay (Figure 1B). Serial dilutions (0.1 to $10,000 \mathrm{pg} / \mathrm{ml}$ ) of HIV-1 p24 antigen were added onto microplate wells precoated with $1 \mathrm{G} 12 \mathrm{mAb}$ followed by the addition of GNPs. The amount of bio-barcode DNA on the captured GNPs was measured by PCR and gel electrophoresis. The signal of the $47 \mathrm{bp}$ PCR products in 3 independent experiments were measured. The cutoff value was 0.098 (mean plus $3 \mathrm{SD}$ ). The SD (Figure 2) and coefficient of variations (3.4-13.1\%) of the entire data point range were small. The LOD of this assay was $1 \mathrm{pg} / \mathrm{ml}$ (Figure 2) and the linear detection range of p24 was from 1 to $10,000 \mathrm{pg} / \mathrm{ml}$ (Figure 3B).

\section{Detection of HIV-1 p24 antigen by BCA using MMPs}

We further substituted the microplate with magnetic microparticles to increase the binding kinetics between the p24 antigen and capture mAb (Figure 1C). The measurement of p24 by PCR and gel electrophoresis remained the same as described above. The cutoff value was 0.125 (mean of 3 determinations and 3 SD). The SD (Figure 2) and coefficient of variations (2.5-10.3\%) of the entire data point range were small. The LOD of this assay was improved to $0.1 \mathrm{pg} / \mathrm{ml}$ (Figure 2) and the linear detection range of p24 was from 0.1 to $1,000 \mathrm{pg} / \mathrm{ml}$ of p24 (Figure 3C).

\section{Discussion}

BCA-based assays have become a new platform frequently used to detect trace proteins requiring high sensitivity detection $[18,23,24]$. It has been applied to the early diagnosis of cancer markers and infectious diseases such as prostate-specific antigen (PSA) [15,16], human chorionic gonadotropin and $\alpha$-fetoprotein [25], amyloid- $ß$-derived diffusible ligand [26], interleukin-2 [23], Hantaan viral nucleocapsid protein [22] and HIV-1 p24 antigen [17,19,21]. Likewise, here we showed that BCA-based microplate and MMP assays coupled with PCR signal amplification offer greater detection sensitivity over an ELISA assay by 1,000 to 10,000 fold, respectively. The increase of signal is achieved by (1) the large number of bio-barcode DNA oligomer coated onto the GNPs [20,25] and (2) PCR amplification of the biobarcode DNA released from the GNPs after specific p24 and $\mathrm{mAb}$ capture.

Several forms of signal amplification methods have been used including chip-based scanometric detection $[15,19,25,26]$, colormetric method [23], and fluorescent approach [20]. Kim and colleagues used MMPs and compared real-time PCR and chip-based methods. They found that the two methods performed similarly and 


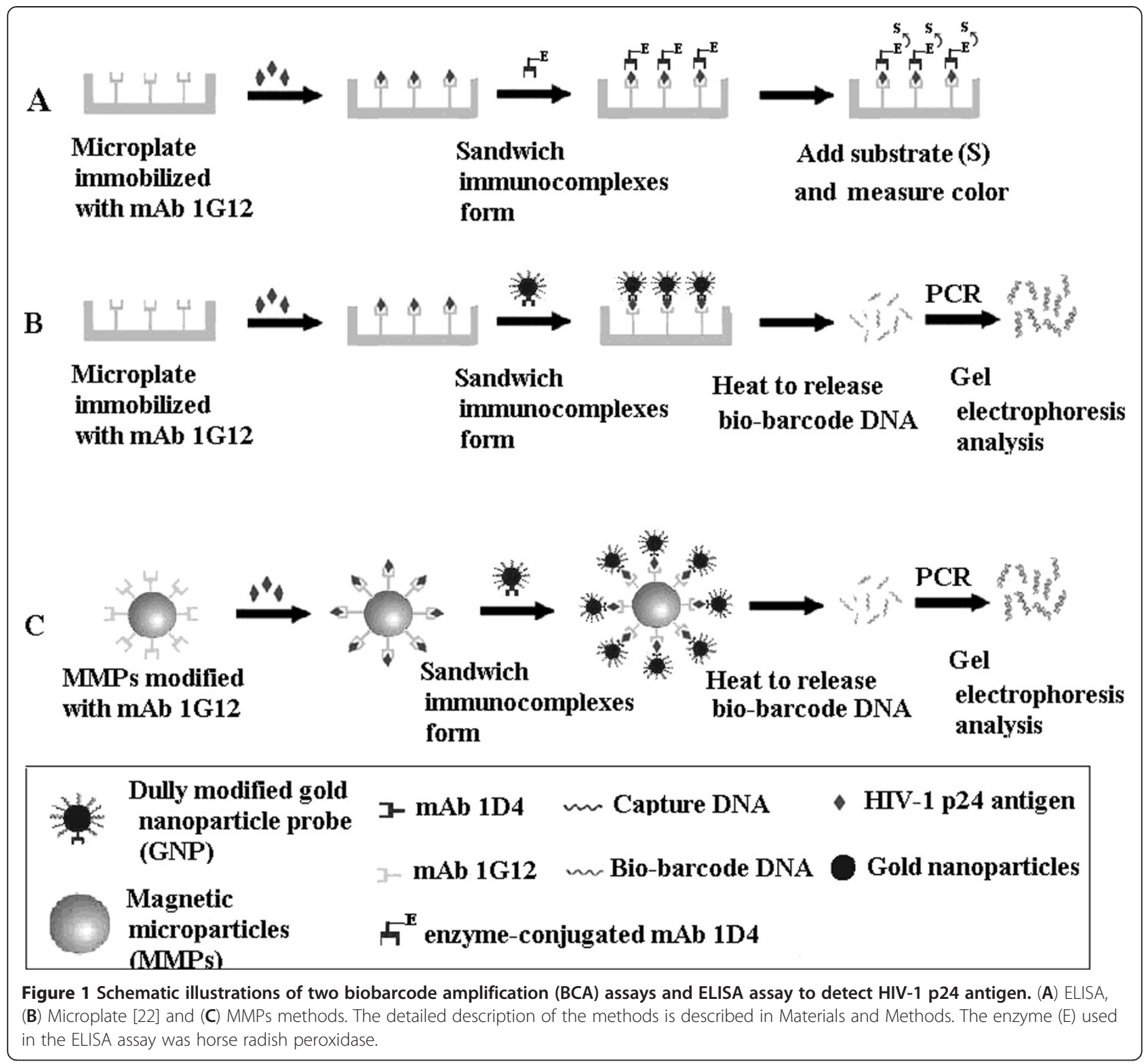

achieved a sensitivity of $0.1 \mathrm{pg} / \mathrm{ml}$ and a detection range from $0.1 \mathrm{pg} / \mathrm{ml}$ to $10,000 \mathrm{pg} / \mathrm{ml}$ [21]. Tang used a BCAbased microplate assay combined with chip-based method to achieve an LOD of HIV-1 p24 at $0.1 \mathrm{pg} / \mathrm{ml}$ with the linear range of $0.1-500 \mathrm{pg} / \mathrm{ml}$ [19]. In an attempt to simplify assay procedures and shorten the reaction time, Tang et al., used europium nanoparticles to replace GNPs, but the LOD increased from 0.1 to $0.5 \mathrm{pg} / \mathrm{ml}$ [17]. In this report, we showed that our MMP assay was reproducible with small $\mathrm{SD}$ and $\mathrm{CV}$. It achieved 10-fold detection sensitivity over that of the microplate method. Our MMP assay has comparatively simpler operation and shorter reaction time than those reported earlier [21] and we achieved the same LOD and a wider linear range of 0.1 to $1,000 \mathrm{pg} / \mathrm{ml}$ in two hours.
One of the disadvantages of PCR-based methods is the potential of cross-contamination. Although this phenomenon was not observed in our study, measures to avoid PCR contamination should be strictly observed $[27,28]$. We had attempted the use of real-time PCR with SYBR Green to replace gel-based quantification but we found the magnitude of signal amplification over the intended detection range of p24 was suboptimal (data not shown). One of the important applications of p24 detection in China is to identify HIV-infected infants born to HIV-infected mothers. Currently there is no government-approved domestic HIV-1 p24 or nucleic acid-based technologies available. We will continue improving the current procedures by identifying a better $\mathrm{mAb}$ pair for the p24 and GNP complex formation and 


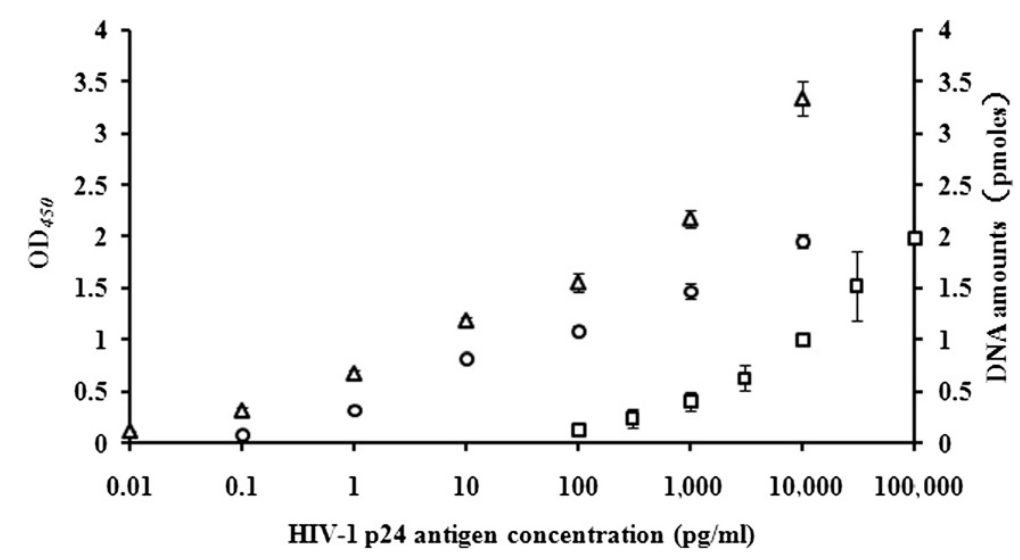

Figure 2 Relative HIV-1 p24 antigen detection sensitivity using 2 BCA-based assays and an in-house ELISA assay. The X axis represents serial dilutions ( $\log _{10}$ ) of HIV-1 p24 antigen, the left $Y$ axis is $\mathrm{OD}_{450}$ value for ELISA, and the right $Y$ axis is the DNA amounts (pmoles) calculated from gel electrophoresis band of samples for the two BCA assays. Each data point represents the average of 3 independent determinations. Squares : ELISA, circles: microplate method, and triangles: MMPs method.

assembling a contamination free real-time PCR system for the accurate and rapid identification of HIV infection.

\section{Conclusions}

Our current study demonstrated that when combined with PCR and gel analysis, BCA-based assays using microplates and MMPs can detect HIV-1 p24 antigen 3 to 4 orders of magnitude more sensitive than the conventional ELISA assay and offers a wide linear dynamic range. This assay may be useful in China to detect HIV infection in infants born to HIV-infected mothers.

\section{Materials and methods}

\section{HIV p24 antigen and its monoclonal antibodies}

HIV-1 p24 recombinant antigen was purchased from GenWay Biotech (San Diego, CA). Mouse anti-p24 monoclonal antibody, $1 \mathrm{G} 12$ and 1D4, and their corresponding horseradish peroxidase-labeled mAbs were purchased from Jing Tiancheng biology company (Beijing, China). These two mAbs recognize different p24 epitopes. The $1 \mathrm{G} 12 \mathrm{mAb}$ was used to capture p24 and 1D4 mAb was used as the secondary antibody for signal detection.

\section{Oligonucleotides and reagents}

Bio-barcode DNA was 47-base in length and its sequence, 5'-CAGCTGGTCAGCAGAATGGTGTGACCCT CATGGCCGTCTTATCGGGT-3, was derived from AT4G27630.1 (accessed December 25, 2011 at http:// www.arabidopsis.org/index.jsp). Capture DNA sequence is complementary to the Bio-barcode DNA with an addition of an $\mathrm{SH}$ group and $15 \mathrm{~A}$ residues at its 5 ' end. The forward primer (5'-CAGCTGGTCAGCAGAATGGTG-3') and reverse primer (5'-ACCCGATAAGACGGCCATGAG-3') were used for the PCR amplification of bio-barcode DNA.
All oligonucleotides were purchased from Sangon Co. Ltd. (Shanghai, China). PCR reagents were purchased from TaKaRa Biotechnology Co., Ltd (Dalian, China). Gold nanoparticles of $30 \mathrm{~nm}$ in diameter and tosyl-activated magnetic microparticles $\left(\right.$ MyOne $^{\mathrm{TM}}$ Dynabeads $^{\circledR}$ ) were purchased from Ted Pella Inc (Redding, CA) and Invitrogen (Carlsbad, CA), respectively.

\section{Preparation of functionalized MMPs}

MyOne $^{\mathrm{TM}}$ Dynabeads $^{\circledR}$ were conjugated with $1 \mathrm{G} 12 \mathrm{mAb}$ according to manufacturer's protocol. Briefly, $40 \mu \mathrm{l}$ $1 \mathrm{G} 12 \mathrm{mAb}(1 \mathrm{mg} / \mathrm{ml}), 10 \mu \mathrm{l}$ magnetic microparticles, $42 \mu \mathrm{l} 3 \mathrm{M}\left(\mathrm{NH}_{4}\right)_{2} \mathrm{SO}_{4}$ and $66 \mu \mathrm{l}$ borate buffer $(0.1 \mathrm{M}$, $\mathrm{pH}$ 9.5) were combined in a $1.5 \mathrm{ml}$ tube and incubated at $37^{\circ} \mathrm{C}$ at 1400 oscillations per minute for $24 \mathrm{~h}$. The MMPs were separated from unbound components magnetically. Three hundred $\mu \mathrm{l}$ of blocking buffer consisting of phosphate-buffered saline (PBS), $\mathrm{pH} 7.4,10 \%$ BSA and $0.05 \%$ Tween 20 was added and the MMPs mixture was incubated at $37^{\circ} \mathrm{C}$ at 1400 oscillations per minute for another $24 \mathrm{~h}$. At the completion of incubation, the MMPs were separated magnetically and were washed twice with $1 \mathrm{ml}$ of magnetic-probe solution containing PBS pH 7.4, 0.1\% BSA and 0.05\% Tween 20, and resuspended in $200 \mu \mathrm{l}$ of the same solution and stored at $4^{\circ} \mathrm{C}$ until use. Functionalized MMPs retained their antigen binding activity for 4-6 months

\section{Preparation of functionalized GNPs}

GNPs functionalized with 1D4 mAb and the capture DNA oligomers were prepared as described previously [22]. Briefly, the $\mathrm{pH}$ of GNPs in aqueous solution (330 pM) was first adjusted to $\mathrm{pH} 9.2$ with $1 \mathrm{~N} \mathrm{NaOH}$. One $\mathrm{ml}$ of the solution was incubated with $6 \mu \mathrm{g} 1 \mathrm{D} 4 \mathrm{mAb}$ 

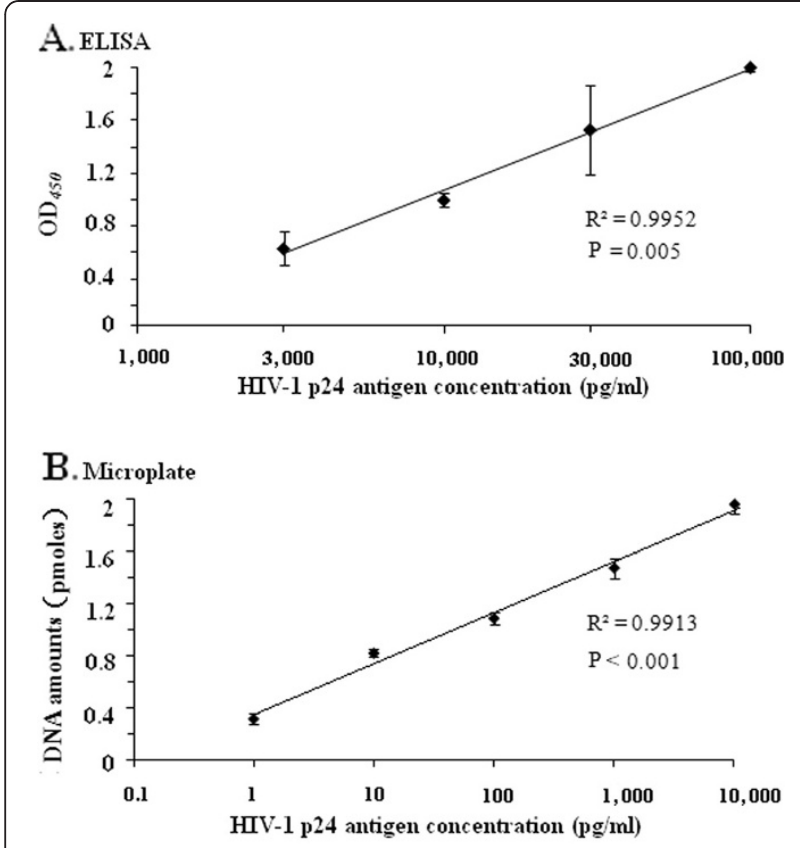

C.MMPs

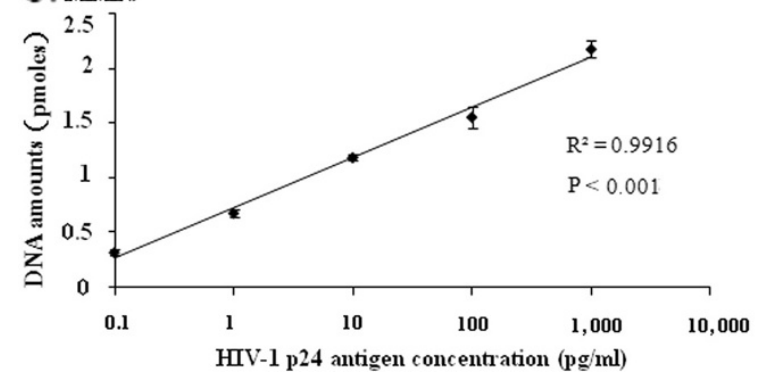

Figure 3 Linear dynamic p24 detection ranges of three assays: (A) in-house ELISA, (B) BCA-based microplates and (C)

BCA-based MMPs. Each data point represents the average of three independent determinations. Statistical analysis of linear regression model between the signal value of each methods and the concentration of HIV-1 p24 are carried out with SPSS 16.0.

at $22^{\circ} \mathrm{C}$ with gentle shaking for $30 \mathrm{~min}$, followed by the addition of $57.7 \mu \mathrm{g}$ capture DNA oligomer at $10^{\circ} \mathrm{C}$ for $16 \mathrm{~h}$. The salt concentration was then adjusted to $0.1 \mathrm{M}$ using $2 \mathrm{M} \mathrm{NaCl}$ followed with the addition of $0.3 \mathrm{ml}$ of $10 \%$ BSA. The mixture was incubated at $22^{\circ} \mathrm{C}$ for $30 \mathrm{~min}$ and then centrifuged at $10,000 \mathrm{rpm}$ at $4^{\circ} \mathrm{C}$ for $30 \mathrm{~min}$. The supernatant was removed and the GNPs were resuspended and washed once with $0.01 \mathrm{M}$ PBS. The particles were resuspended with $400 \mu \mathrm{l}$ PBS containing $65.5 \mu \mathrm{g}$ of the signal DNA oligomers and allowed to hybridize at $37^{\circ} \mathrm{C}$ for $1 \mathrm{~h}$. Finally, the GNPs were centrifuged at 10,000 rpm (Eppendorf centrifuge $5415 \mathrm{R}$, Germany) at $4^{\circ} \mathrm{C}$ for $30 \mathrm{~min}$ and then resuspended in PBS containing $0.01 \%(\mathrm{v} / \mathrm{v})$ Tween 20 and $0.1 \%(\mathrm{w} / \mathrm{v})$ BSA. The functionalized GNPs solution was stored at $4^{\circ} \mathrm{C}$ until use.

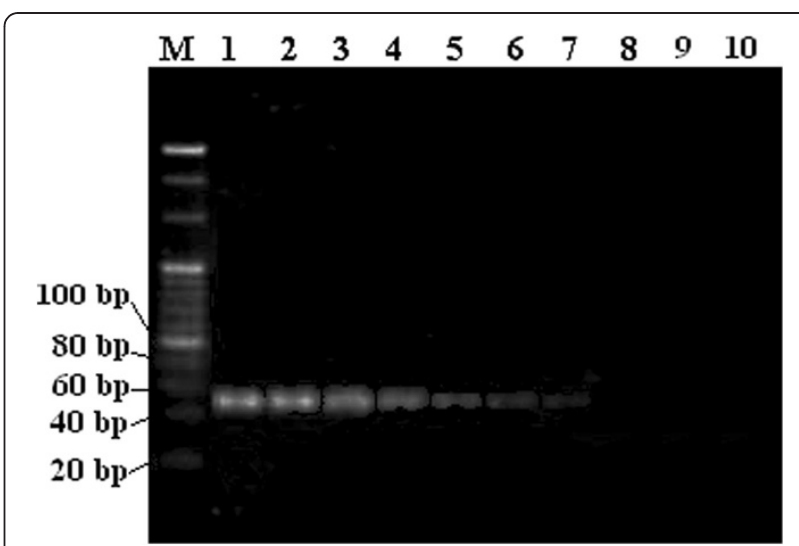

Figure 4 Amplification detection of 10 -fold diluted bio-barcode is revealed by $4 \%$ agarose gel electrophoresis. The concentration of DNA in lane 1 was $0.005 \mathrm{uM}$ and $5 \mu \mathrm{l}$ of PCR DNA were used for gel electrophoresis. Lane $\mathrm{M}$ is the $20 \mathrm{bp}$ ladder reference DNA marker (Takara Inc.). Lanes 1 to 9 represents amplicons $3 \times 10^{9}, 3 \times 10^{8}, 3 \times 10^{7}, 3 \times 10^{6}, 3 \times 10^{5}, 3 \times 10^{4}, 3 \times 10^{3}$, 300 , and 30 copies of signal bio-barcode DNA. Lane 10 represents negative control (PCR reaction mixture without input DNA).

\section{Detection of HIV-1 p24 antigen by ELISA}

Microplate strips (Corning Costar Inc., Lowell, MA) were coated with $100 \mu \mathrm{l}$ per well of $1 \mathrm{G12} \mathrm{mAb}(5 \mu \mathrm{g} / \mathrm{ml}$ in $0.5 \mathrm{M}$ carbonate buffer) at $4^{\circ} \mathrm{C}$ for $24 \mathrm{~h}$. After incubation, the strips were washed twice with PBS and then treated with $10 \% \mathrm{BSA}$ at $37^{\circ} \mathrm{C}$ for $24 \mathrm{~h}$ to block the surface. The strips were washed again and then coated with $100 \mu \mathrm{l}$ per well of serially diluted p24 antigen (ranged from 0.1 to $100,000 \mathrm{pg} / \mathrm{ml}$ ) by incubating at $37^{\circ} \mathrm{C}$ for $1.5 \mathrm{~h}$. Unbound antigens were washed 3 times with PBS. One hundred $\mu \mathrm{l}$ of 1,000 fold diluted HRP-labeled 1D4 was added to each well and the plate was incubated at $37^{\circ} \mathrm{C}$ for $1 \mathrm{~h}$ followed with 6 washes with PBS. One hundred $\mu \mathrm{l}$ of tetramethylbenzidine was then added to each well and the plate was incubated at $22^{\circ} \mathrm{C}$ for $15 \mathrm{~min}$. The enzymatic reaction was terminated with the addition of $50 \mu \mathrm{l}$ of $2 \mathrm{M} \mathrm{H}_{2} \mathrm{SO}_{4}$, and the color was quantified in an ELx808 plate reader (BioTek, Seattle, WA) at the wavelength of $450 \mathrm{~nm}$.

\section{Detection of HIV-1 p24 antigen by BCA based on microplate}

The assay scheme is shown in Figure 1B. The coating of $\mathrm{BCA}$ and blocking processes of microplates were the same as in ELISA. One hundred $\mu \mathrm{l}$ of 10 fold serially diluted HIV-1 p24 (0.1 to $10,000 \mathrm{pg} / \mathrm{ml})$ in PBS containing 3\% BSA was added into $1 \mathrm{G} 12 \mathrm{mAb}$ coated wells. After incubation at $37^{\circ} \mathrm{C}$ for $60 \mathrm{~min}$, the wells were washed 5 times with PBS containing $5 \mathrm{mM}$ EDTA and 0.05\% (v/v) and Tween 20 (PBSET). Then $100 \mu \mathrm{l}$ GNPs (with a final concentration of $50 \mathrm{pM}$ in $10 \% \mathrm{BSA}$ ) were added into each well and incubated at $37^{\circ} \mathrm{C}$ for $20 \mathrm{~min}$. 
The wells were washed 7 times with PBSET and 3 times with PBS and once with $50 \mu \mathrm{l}$ of Milli-Q distilled water. Finally, the wells were membrane sealed and heated in a water bath at $80^{\circ} \mathrm{C}$ for 5 min to release the captured signal DNA oligomers.

PCR amplification was performed by adding $1 \mu \mathrm{l}$ of the free bio-barcode DNA solutions as templates. Total volume of the PCR reaction mixture was $25 \mu \mathrm{l}$ containing $2.5 \mu \mathrm{L}$ 10x Ex Taq Buffer $\left(\mathrm{Mg}^{2+}\right), 2 \mu \mathrm{l}$ dNTPs (2.5 mM each), $0.5 \mu \mathrm{l}$ each of forward and reverse primers (with final concentration of $20 \mu \mathrm{M}$ each), $1 \mu \mathrm{l}$ Bio-barcode DNA, and 0.8 unit of TaKaRa Ex Taq polymerase. PCR reaction was run on Veriti 96-well thermal Cycler (Applied Biosystems, Foster City, CA) with the following temperature profile: initial denaturation, $95^{\circ} \mathrm{C}$, $1 \mathrm{~min} ; 25$ cycles of denaturation $\left(95^{\circ} \mathrm{C}, 30 \mathrm{~s}\right)$, annealing $\left(54^{\circ} \mathrm{C}, 30 \mathrm{~s}\right)$, and extension $\left(72^{\circ} \mathrm{C}, 45 \mathrm{~s}\right)$; and final extension $\left(72^{\circ} \mathrm{C}, 5 \mathrm{~min}\right)$. Five $\mu \mathrm{l}$ of the PCR product was electrophoresed in a $4 \%$ agarose gel and the signal of the amplified 47-bp bio-barcode DNA was measured using GeneGenius Gel Imaging System (Syngene, Cambridge, UK) and BandScan version 5.0 [29,30]. The $100 \mathrm{bp}$ DNA band of the 20 bp DNA Ladder (Takara, Dalian, China) standard with known input amount prior to gel electrophoresis was used as the DNA reference. The gray scale of electrophoresed 47 bp product was directly compared with the reference and its DNA amounts (in pmoles) were automatically determined by BandScan.

\section{Detection of HIV-1 p24 antigen by BCA based on MMPs}

The assay scheme is shown in Figure 1C. One hundred $\mu \mathrm{l}$ of ten-fold serial dilutions of HIV-1 p24 antigen $(10,000 \sim 0.01 \mathrm{pg} / \mathrm{ml})$ in $3 \%$ BSA, $0.2 \%$ Tween 20 , PBS $(\mathrm{pH}$ 7.4) and $40 \mu \mathrm{l}$ diluted functionalized MMPs (1:100 diluted in PBS containing 1\% BSA and 0.2\% Tween 20) were mixed in a tube of $1.5 \mathrm{ml}$ for $60 \mathrm{~min}$ (1,400 oscillations $/ \mathrm{min}$ ) at $37^{\circ} \mathrm{C}$, followed by 5 washes with PBS containing $0.1 \%$ BSA, $0.05 \%$ Tween 20. After magnetic separation, $0.5 \mu \mathrm{l}$ functionalized GNPs and $3.3 \mu \mathrm{g}$ tRNA (66 mg/ml, Sigma-Aldrich, Inc., St. Louis, MO) in PBS containing $10 \%$ BSA and $0.05 \%$ Tween 20 in a total volume of $200 \mu \mathrm{l}$ were added in this reaction, followed by mixing for $20 \mathrm{~min}$ (1400 oscillations/min). The mixture was washed 8 times with PBS containing 0.1\% BSA and 0.05\% Tween 20 and 4 times with PBS. After magnetic separation, $50 \mu \mathrm{l}$ of Milli-Q distilled water was added and the tubes were incubated at $80^{\circ} \mathrm{C}$ for $5 \mathrm{~min}$ to release bio-barcode DNA. One $\mu \mathrm{l}$ of the DNA solution was used for PCR amplification. PCR products were quantified as described in the previous section.

\section{Competing interests}

The authors declare no competing interests.

\section{Authors' contributions}

HD developed the design of the study, performed the experiments, and drafted the manuscript. CO contributed scientific input and manuscript preparation. $J$ participated in the design of the study and part of the experiments. HZ, GZ, GX, YX, FQ, JY, and LP participated in acquisition, analysis, and interpretation of data. YJ supervised the studies. All authors read and approved the final manuscript.

\section{Acknowledgment}

The authors would like to thank Lingzhang Meng, Hui Zhang, Xiuhua LV, Lijian Pei, Jun Tao, Zengqiang Wang, Xingmei Li and Serena Fuller for their valuable assistance with preparation of experimental materials. This study was funded by the Twelfth Five Projects of National Science and Technology fund from the Ministry of Science and Technology of China (grant no: 2012ZX10001001-002)

\section{Author details}

${ }^{1}$ National HIV/HCV Reference Laboratory, National Center for AIDS/STD Control and Prevention, Chinese Center for Disease Control and Prevention, Beijing, The People's Republic of China. ${ }^{2}$ HIV Central Confirmatory Laboratory, Beijing Exit and Entry Inspection and Quarantine Bureau, Beijing, The People's Republic of China. ${ }^{3}$ Global AIDS Program-China office, US Centers for Disease Control and Prevention, Beijing, The People's Republic of China.

Received: 19 January 2012 Accepted: 27 August 2012

Published: 31 August 2012

\section{References}

1. Fiebig EW, Wright DJ, Rawal BD, Garrett PE, Schumacher RT, Peddada L, Heldebrant C, Smith R, Conrad A, Kleinman SH, Busch MP: Dynamics of HIV viremia and antibody seroconversion in plasma donors: implications for diagnosis and staging of primary HIV infection. AIDS 2003, 17:1871-1879.

2. Prado JG, Shintani A, Bofill M, Clotet B, Ruiz L, Martinez-Picado J: Lack of longitudinal intrapatient correlation between p24 antigenemia and levels of human immunodeficiency virus (HIV) type 1 RNA in patients with chronic hiv infection during structured treatment interruptions. J Clin Microbiol 2004, 42:1620-1625.

3. Rouet F, Ekouevi DK, Chaix ML, Burgard M, Inwoley A, Tony TD, Danel C, Anglaret $X$, Leroy $V$, Msellati $P$, et al: Transfer and evaluation of an automated, low-cost real-time reverse transcription-PCR test for diagnosis and monitoring of human immunodeficiency virus type 1 infection in a West African resource-limited setting. J Clin Microbio/ 2005, 43:2709-2717.

4. Jennings C, Fiscus SA, Crowe SM, Danilovic AD, Morack RJ, Scianna S, Cachafeiro A, Brambilla DJ, Schupbach J, Stevens W, et al: Comparison of two human immunodeficiency virus (HIV) RNA surrogate assays to the standard HIV RNA assay. J Clin Microbiol 2005, 43:5950-5956.

5. Sivapalasingam S, Essajee S, Nyambi PN, Itri V, Hanna B, Holzman R, Valentine F: Human immunodeficiency virus (HIV) reverse transcriptase activity correlates with HIV RNA load: implications for resource-limited settings. J Clin Microbiol 2005, 43:3793-3796.

6. Respess RA, Cachafeiro A, Withum D, Fiscus SA, Newman D, Branson B, Varnier OE, Lewis K, Dondero TJ: Evaluation of an ultrasensitive p24 antigen assay as a potential alternative to human immunodeficiency virus type 1 RNA viral load assay in resource-limited settings. J Clin Microbiol 2005, 43:506-508.

7. Ribas SG, Ondoa P, Schupbach J, van der Groen G, Fransen K: Performance of a quantitative human immunodeficiency virus type 1 p24 antigen assay on various HIV-1 subtypes for the follow-up of human immunodeficiency type 1 seropositive individuals. J Virol Methods 2003, 113:29-34.

8. Daskalakis D: HIV diagnostic testing: evolving technology and testing strategies. Top Antivir Med 2011, 19:18-22.

9. Finnegan J, Noble KA, Lodha R: Evidence behind the WHO guidelines: hospital care for children: what is the role of HIV antigen testing in infants <12-months old? J Trop Pediatr 2009, 55:216-218.

10. George E, Beauharnais CA, Brignoli E, Noel F, Bois G, De Matteis RP, Altenor M, Lauture D, Hosty M, Mehta S, et al: Potential of a simplified p24 assay for early diagnosis of infant human immunodeficiency virus type 1 infection in Haiti. J Clin Microbiol 2007, 45:3416-3418. 
11. Allain JP, Laurian Y, Paul DA, Senn D: Serological markers in early stages of human immunodeficiency virus infection in haemophiliacs. Lancet 1986, 2:1233-1236.

12. Schupbach J, Flepp M, Pontelli D, Tomasik Z, Luthy R, Boni J: Heat-mediated immune complex dissociation and enzyme-linked immunosorbent assay signal amplification render p24 antigen detection in plasma as sensitive as HIV-1 RNA detection by polymerase chain reaction. AIDS 1996, 10:1085-1090.

13. Sutthent R, Gaudart N, Chokpaibulkit K, Tanliang N, Kanoksinsombath C, Chaisilwatana P: p24 Antigen detection assay modified with a booster step for diagnosis and monitoring of human immunodeficiency virus type 1 infection. J Clin Microbiol 2003, 41:1016-1022.

14. Barletta JM, Edelman DC, Constantine NT: Lowering the detection limits of HIV-1 viral load using real-time immuno-PCR for HIV-1 p24 antigen. Am J Clin Pathol 2004, 122:20-27.

15. Nam JM, Thaxton CS, Mirkin CA: Nanoparticle-based bio-bar codes for the ultrasensitive detection of proteins. Science 2003, 301:1884-1886.

16. Bao YP, Wei TF, Lefebvre PA, An H, He L, Kunkel GT, Muller UR: Detection of protein analytes via nanoparticle-based bio bar code technology. Anal Chem 2006, 78:2055-2059.

17. Tang S, Hewlett I: Nanoparticle-based immunoassays for sensitive and early detection of HIV-1 capsid (p24) antigen. J Infect Dis 2010, 201(Suppl 1):S59-S64.

18. Thaxton CS, Elghanian R, Thomas AD, Stoeva SI, Lee JS, Smith ND, Schaeffer AJ, Klocker H, Horninger W, Bartsch G, Mirkin CA: Nanoparticle-based biobarcode assay redefines "undetectable" PSA and biochemical recurrence after radical prostatectomy. Proc Natl Acad Sci U S A 2009, 106:18437-18442.

19. Tang S, Zhao J, Storhoff JJ, Norris PJ, Little RF, Yarchoan R, Stramer SL, Patno T, Domanus M, Dhar A, et al: Nanoparticle-Based biobarcode amplification assay (BCA) for sensitive and early detection of human immunodeficiency type 1 capsid (p24) antigen. J Acquir Immune Defic Syndr 2007, 46:231-237.

20. Oh BK, Nam JM, Lee SW, Mirkin CA: A fluorophore-based bio-barcode amplification assay for proteins. Small 2006, 2:103-108.

21. Kim EY, Stanton J, Korber BT, Krebs K, Bogdan D, Kunstman K, Wu S, Phair JP, Mirkin CA, Wolinsky SM: Detection of HIV-1 p24 Gag in plasma by a nanoparticle-based bio-barcode-amplification method. Nanomedicine (Lond) 2008, 3:293-303.

22. Chen L, Wei H, Guo Y, Cui Z, Zhang Z, Zhang XE: Gold nanoparticle enhanced immuno-PCR for ultrasensitive detection of Hantaan virus nucleocapsid protein. J Immunol Methods 2009, 346:64-70.

23. Nam JM, Wise AR, Groves JT: Colorimetric bio-barcode amplification assay for cytokines. Anal Chem 2005, 77:6985-6988.

24. Thaxton CS, Hill HD, Georganopoulou DG, Stoeva SI, Mirkin CA: A bio-bar-code assay based upon dithiothreitol-induced oligonucleotide release. Anal Chem 2005, 77:8174-8178.

25. Stoeva SI, Lee JS, Smith JE, Rosen ST, Mirkin CA: Multiplexed detection of protein cancer markers with biobarcoded nanoparticle probes. J Am Chem Soc 2006, 128:8378-8379.

26. Georganopoulou DG, Chang L, Nam JM, Thaxton CS, Mufson EJ, Klein WL, Mirkin CA: Nanoparticle-based detection in cerebral spinal fluid of a soluble pathogenic biomarker for Alzheimer's disease. Proc Natl Acad Sci U S A 2005, 102:2273-2276.

27. Pruvost $M$, Grange T, Geigl EM: Minimizing DNA contamination by using UNG-coupled quantitative real-time PCR on degraded DNA samples: application to ancient DNA studies. Biotechniques 2005, 38:569-575.

28. Ho PS, Ng MM, Chu JJ: Establishment of one-step SYBR green-based real time-PCR assay for rapid detection and quantification of chikungunya virus infection. Virol J 2010, 7:13.

29. Wen J, Chiang YJ, Gao C, Xue H, Xu J, Ning Y, Hodes RJ, Gao X, Chen YG Loss of Dact1 disrupts planar cell polarity signaling by altering dishevelled activity and leads to posterior malformation in mice. $J$ Biol Chem 2010, 285:11023-11030.

30. Feugate JE, Li Q, Wong L, Martins-Green M: The cxc chemokine CCAF stimulates differentiation of fibroblasts into myofibroblasts and accelerates wound closure. J Cell Biol 2002, 156:161-172.

doi:10.1186/1743-422X-9-180

Cite this article as: Dong et al:: Two types of nanoparticle-based bio-barcode amplification assays to detect HIV-1 p24 antigen. Virology Journal 2012 9:180.

\section{Submit your next manuscript to BioMed Central and take full advantage of:}

- Convenient online submission

- Thorough peer review

- No space constraints or color figure charges

- Immediate publication on acceptance

- Inclusion in PubMed, CAS, Scopus and Google Scholar

- Research which is freely available for redistribution 